\title{
New Water Soluble Lauroyl Lysine Derivative and Its Unique Physicochemical Properties for Cosmetics Applications*
}

\author{
Shun Kobayashi ${ }^{* *}$, Kazuhiko Tobita ${ }^{* * *}$, Eiko Oshimura** \\ ** Research Institute for Bioscience Products \& Fine Chemicals, Ajinomoto Co., Inc, \\ *** Specialty Chemicals Department Amino Science Division, Ajinomoto. Co., Inc
}

\begin{abstract}
$N^{\varepsilon}$-lauroyl lysine is an organic powder that is sparingly soluble in many kinds of cosmetic media. It is well known as a beneficial ingredient in various cosmetic applications; its excellent lubricity, water-repellency and non-greasy emolliency make it an ideal ingredient especially for makeups. However, its use in liquid formulations has been restricted because its inherent hydrophobicity makes it difficult to disperse in aqueous media. We developed derivatives of $N^{\varepsilon}$-lauroyl lysine to find a compound soluble in water, and studied its characteristics as a cosmetic ingredient. New bis $\left(N^{\varepsilon}\right.$-lauroyl lysine $)$ derivatives, which have gemini-type surfactant structures, composed of two $N^{\varepsilon}$-lauroyl lysines linked by alkylene chains of various lengths, were synthesized, and their properties in aqueous media were examined. We observed that a compound with an alkylene chain length of $\mathrm{C} 10$ (labeled GE-10-LL) formed hydrogel structured by a three-dimensional nanofiber network over a $\mathrm{pH}$ range of 5.0-7.0. Fourier transform infrared spectroscopy measurements revealed that GE-10-LL worked as a low molecular gelator, resulting in the formation of self-assembled nanofibers through hydrogen bonding. Additionally, GE-10-LL was observed to be an effective foam booster for various foaming surfactants, and to be a sensory modifier with beneficial characteristics of the original $N^{\varepsilon}$-lauroyl lysine. In addition, GE-10-LL can easily form multilamellar vesicles (MLVs) with sterol ester. These MLVs can be prepared by stirring spontaneously, and they could encapsulate water-soluble active ingredients. We measured the penetration of MLVs into the stratum corneum using in vivo confocal Raman spectroscopy.
\end{abstract}

Key words : $N^{\varepsilon}$-lauroyl lysine, gemini-type surfactant, multilamellar vesicle, self-assembled nanofibers, hydrogel, foam booster, lubricity, penetration, sterol ester, in vivo confocal Raman spectroscopy.

\footnotetext{
* Received, September 29, 2017; Accepted, December 7, 2017

** 1-1, Suzuki-cho, Kawasaki-ku, Kawasaki 210-8681, Japan

*** 1-15-1, Kyobashi, Chuo-ku, Tokyo 104-8315, Japan
}

doi.org/10.5107/sccj.52.92

(C) 2018 The Society of Cosmetic Chemists of Japan 


\title{
新規水溶性ラウロイルリジン誘導体の 物理化学的評価と化粧品用途への応用*
}

\author{
小林 瞬**, 飛田和 彦***, 押 村 英子**, \\ **味の素株式会社 バイオ・ファイン研究所, ***味の素株式会社 化成品部
}

\begin{abstract}
アミノ酸系機能性粉体である $N^{\varepsilon}-$ ラロイルリジンは, 優れた滑沢性·撥水性を有し, メイクアッ プ化粧料をはじめ, 幅広い化粧品に配合されている。しかし, $N^{\varepsilon}$-ラウロイルリジンは, 水にも油に も難溶性であるため, スキンケア商品や液体洗浄料などの液体剅型に対し, 安定に配合することが難 しかった。本研究では, $N^{\varepsilon}-$ ラウロイルリジンの特長を維持しつつ, 液体化粧料への配合を容易とす ることを目的とし, 水溶性 $N^{\varepsilon}-$ ラウロイリジン誘導体の合成検討を行った。結果, 2 分子の $N^{\varepsilon}-$ ラウロイルリジンとセバシン酸から形成されるジェミ二型誘導体は, pH 7 以上のアルカリ性領域で は水に可溶であるものの, 弱酸性〜中性領域で水をゲル化させるというユ二ークな特長を有してい た。なお, TEM 観察の結果から, ジェミ二型誘導体は自己集合体化により繊維構造を形成し，ゲル 化能が発現していることが示唆された。また一方で, ジェミ二型誘導体と特定の添加剤を組み合わせ ることにより，マルチラメラベシクルを形成することを見出した。本稿では，これらの詳細な検討と 化粧品用途への応用について報告する。
\end{abstract}

\section{1. 緒言}

$N^{\varepsilon}$-ラウロイルリジン (Fig.-1）は，発酵由来のアミノ

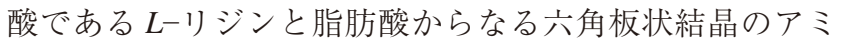
ノ酸系機能性粉体（Fig.-2）であり，その特長として，滑 沢性に優れ，シルキーな感触を持つほか, 無機粉体の表面 に吸着して，撥水性を付与し，流動性を向上させるなどの 表面改質効果を有する。そのため, 感触改良剂, 顔料分散 剤として，メイクアップ製品で使用されているほかに，ス キンケア，へアケア製品にも幅広く使用されている化合物 である11。

しかし, その反面, $N^{\varepsilon}$-ラウロイルリジンは水にも油に 溶けない性質を示すために, 化粧水や乳液, ヘアシャン プーといった液体化粧料へ安定的に配合するには相応の処 方技術が必要である，という課題もあった。

そこで, 本研究では, 2 分子の $N^{\varepsilon}$-ラウロイルリジンか ら形成されるジェミニ型構造に着目した。一般に， 1 鎖 1 親水基型の界面活性剤が架橋した構造を有するジェミニ型 界面活性剂は, 通常の 1 鎖 1 親水基型界面活性剤と比較し てきわめて低い臨界ミセル濃度 $(\mathrm{cmc})$ を示すことや, 低

\footnotetext{
*2017.9.29 受付, 2017.12 .7 採用

**テ212-8681 川崎市川崎区鈴木町 1-1

*** $=104-8315$ 東京都中央区京橋 1-15-1
}

濃度領域でひも状ミセルやベシクルなどの高次な分子集合 体を自発的に形成することが報告されている2 24

本稿では, 前半にジェミ二型構造を有する $N^{\varepsilon}$-ラウロイ ルリジン誘導体が自発的に形成する $\mathrm{pH}$ 応答型分子集合体 に関して報告し，後半に特定の化合物と混合した際に形成 するマルチラメラベシクル製剤に関して報告する。

\section{2. 実験}

\section{1. 試料}

$N^{\varepsilon}$-ラウロイルリジンと炭素鎖 4〜10 の末端ジカルボン 酸を脱水縮合させ（Fig.-3），評価試料を得た。

ついで, 得られた各評価試料 0.5 重量\%水溶液を $\mathrm{pH} 9.0$ に調整し，目視にて溶状観察を行った。結果，末端ジカルボ ン酸の炭素鎖長が 8 以下だと水へ溶解しなかった $($ Table-1)。 そのため, 本研究では炭素鎖長 10 のセバシン酸で $N^{\varepsilon}-$ ラ ウロイルリジンを架橋したジェミニ型誘導体（以下，GE10-LL）を使用することとした。

\section{2. 中和滴定}

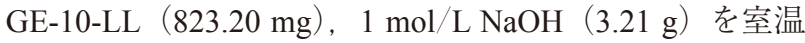
にて均一に混合したのちに，精製水で $100 \mathrm{~mL}$ ヘメスアッ プした。得られた $10 \mathrm{mmol} / \mathrm{L} \mathrm{GE}-10-\mathrm{LL}$ 水溶液に対して, $0.1 \mathrm{~mol} / \mathrm{L} \mathrm{HCl}$ を $0.2 \mathrm{~g}$ ずつ滴下して中和滴定曲線を得た。 


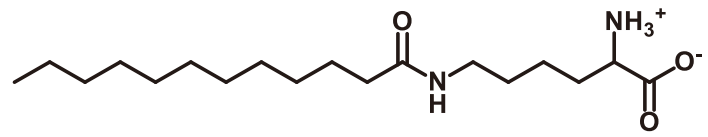

Fig.-1 Chemical Structure of $N^{\varepsilon}$-lauroyl lysine.

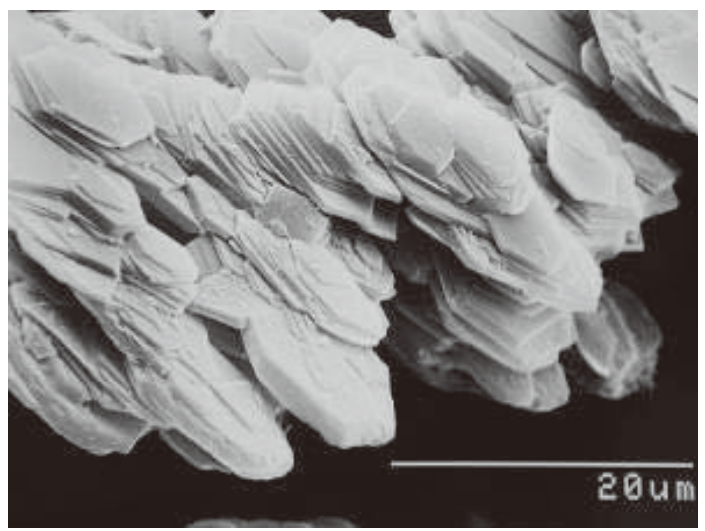

Fig.-2 Crystal shape of $N^{\varepsilon}$-lauroyl lysine.

\section{3. ハイドロゲル：電子顕微鏡観察}

サンプルにコロジオンおよび TEM 用グリッドメッシュ を加え, 液体窒素で凍結させた後, 減圧条件下, サンプル を乾燥させた。ついで, オスミウムでネガティブ染色し, 透過型電子顕微鏡 JEM-2010（日本電子社製）を用いて, 加速電圧 $200 \mathrm{kV}$ で観察した。

\section{4. 赤外吸収スペクトル測定}

フーリエ変換赤外分光光度計 IR Prestige-21（島津製作 所製）を用いて, ATR 法（DuraSamplIR II, Smiths Detection 製）により，サンプルの IR スペクトルを得た。

\section{5. ハンドミキサー法による泡量測定}

$500 \mathrm{~mL}$ ビーカーに 10 重量\%界面活性剂水溶液を $2 \mathrm{~g}$ 量 り入れ, $35^{\circ} \mathrm{C}$ の水道水で希釈して $100 \mathrm{~g}$ とする。その後, 調理用ハンドミキサーにより，3400 rpm で 10 秒擋拌後の 泡量（mL）を読み取った。

\section{6. 動的光散乱による粒径測定}

各測定試料を $1 \mathrm{wt} \%, \mathrm{pH}$ 12〜13 となるように調整した のち, 動的光散乱測定（HPPS, Malvern 製) により, 分子 集合体の粒径分布を確認した。

\section{7. ベシクル：調製方法}

$80^{\circ} \mathrm{C}$ の条件下, GE-10-LL とベシクル形成助剤を混合し, ホモディスパーで $3000 \mathrm{rpm}, 10$ 分間擋拌した。その後, ゆっくり撹拌しながら, 室温まで徐冷して, マルチラメラ ベシクルを得た。

\section{8. ベシクル : 形成確認}

偏光顕微鏡（ECLIPSE LV100POL，ニコン製），および

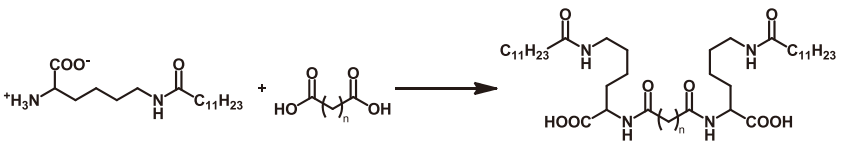

Fig.-3 Synthesis of Bis ( $N^{\varepsilon}$-lauroyl lysine $)$ derivatives.

Table-1 Solubility of $0.5 \mathrm{wt} \%$ solution.

\begin{tabular}{cc}
\hline Spacer length & $\begin{array}{c}\text { Water solubility } \\
(\mathrm{pH} 9)\end{array}$ \\
\hline $\mathrm{C} 4$ & $\mathrm{I}$ \\
$\mathrm{C} 5$ & $\mathrm{I}$ \\
$\mathrm{C} 6$ & $\mathrm{I}$ \\
$\mathrm{C} 7$ & $\mathrm{I}$ \\
$\mathrm{C} 8$ & $\mathrm{I}$ \\
$\mathrm{C} 9$ & $\mathrm{~S}$ \\
$\mathrm{C} 10$ & $\mathrm{~S}$ \\
\hline
\end{tabular}

*I: Insoluble, S: Soluble.

FF-TEM（JFD-V，JEM-1400plus，日本電子製）により， ベシクルの形成を確認した。

\section{9. ベシクル : 平均粒径測定}

レーザー回析/散乱式粒子径分布測定装置（LA-950，堀 場製作所製）を用いて，ベシクルの平均粒径を算出した。

\subsection{0. 角層浸透性評価}

前腕内側部を十分に流水で洗浄した後，試料を塗布し， 恒温恒湿室 $\left(23^{\circ} \mathrm{C}, 40 \mathrm{RH} \%\right)$ で 1 時間馴化した。ついで, in vivo 共焦点ラマン分光装置（gen2-SCA， RiverD 製）に より，塗布部位の角層深さ方向のラマンスペクトルを測 定, ベシクルの浸透性を評価した。

\section{3. 結果・考察}

\subsection{GE-10-LL の水溶液挙動}

$10 \mathrm{mmol} / \mathrm{L} \mathrm{GE}-10-\mathrm{LL}$ 水溶液の中和滴定曲線と $25^{\circ} \mathrm{C}$ にお ける溶液状態を Fig.-4に示す。GE-10-LL は, 分子内に 2 つのカルボキシル基を有するため, 2 回の $\mathrm{pH}$ ジャンプが 確認された。また非常に興味深いことに，第 1 当量点と第 2 当量点の間の領域である中性〜弱酸性領域において，八 イドロゲルを形成した。この領域では, GE-10-LL 中の 1 つのカルボキシル基のみ解離している状態であり，疑似的 に 2 鎖 1 親水基型界面活性剤の構造を形成することで，分 子会合体の挙動に変化が生じたものと考えられる。

一般に低分子アミノ酸系オイルゲル化剂の研究では，水 素結合などの分子間相互作用による繊維状会合体の形成と van der Waals 力による繊維状会合体の結合・3 次元化によ 
り，オイルゲルを形成することが報告5)されており，溶媒 は異なるものの, GE-10-LL も同様のメカニズムでハイド ロゲルを形成しているものと推測する。

\section{2. ハイドロゲルのメカニズム解明}

GE-10-LL が形成するハイドロゲルのメカニズムを解明 するため，電子顕微鏡観察を行った（Fig.-5）。結果，GE10-LLは，仮説どおり，纎維状会合体を形成し，それらが 3 次元的に絡み合うことで水を抱え込み, ハイドロゲルを 形成していることがわかった。

GE-10-LL が形成するハイドロゲルは， $60^{\circ} \mathrm{C}$ 以上で溶液 状態を示すことから， $25^{\circ} \mathrm{C}$ およ゙ $60^{\circ} \mathrm{C}$ におりる赤外吸収 スペクトルを測定した。1600〜 $1700 \mathrm{~cm}^{-1}$ 付近を拡大した 結果を Fig.-6に示す。

一般に，水素結合したアミド結合部位のカルボニル伸縮 運動は $1640 \mathrm{~cm}^{-1}$ と報告 ${ }^{6}$ されており, GE-10-LL が形成す る水ゲルのピークと一致する。また， $60^{\circ} \mathrm{C}$ で測定したサン

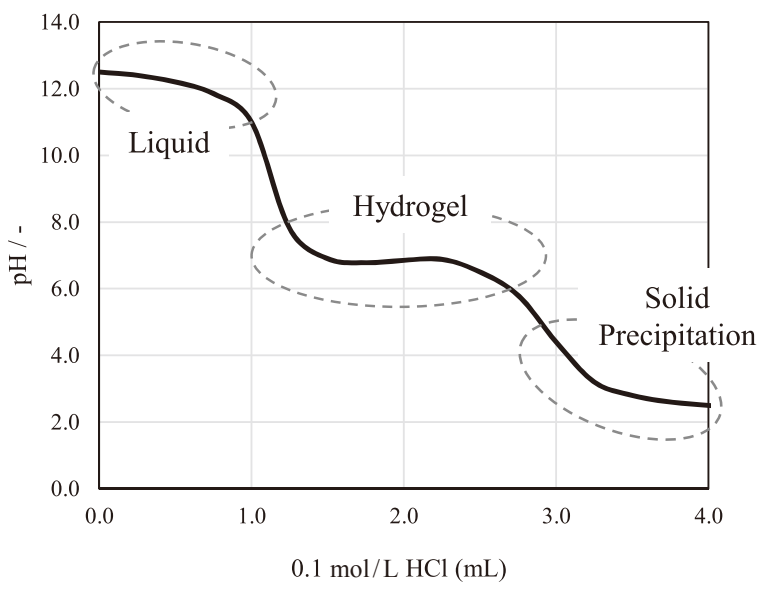

Fig.-4 pH Titration curve and aqueous solution behavior of GE-10-LL.
プルは, カルボニル伸縮運動のピークが $1660 \mathrm{~cm}^{-1}$ 付近に シフトしており，水素結合が消滅していることが示唆され た。すなわち，GE-10-LL が形成する水ゲルは，分子間水 素結合をドライビングフォースとして，繊維状会合体を形 成し，高次ネットワーク構造を形成していることが示唆さ れた。

\subsection{GE-10-LL の洗浄剤用途への応用}

本節では，GE-10-LL を液体洗浄剤に添加した際の効果 を紹介する。当初, GE-10-LLを液体洗浄剤の増粘剤とし て利用するために検討を開始したものの，残念ながら，界 面活性剤水溶液中でハイドロゲルは分散されてしまい，増 粘剤としての効果は発揮されなかった。一方で，消費者に よる官能評価試験を実施したところ，泡立ち改善効果や洗 いあがりの感触が向上する結果が得られた。

泡立ち改善効果を確認するために，ハンドミキサー法に よる界面活性剤の泡量を評価した。本試験では 10 重量\%

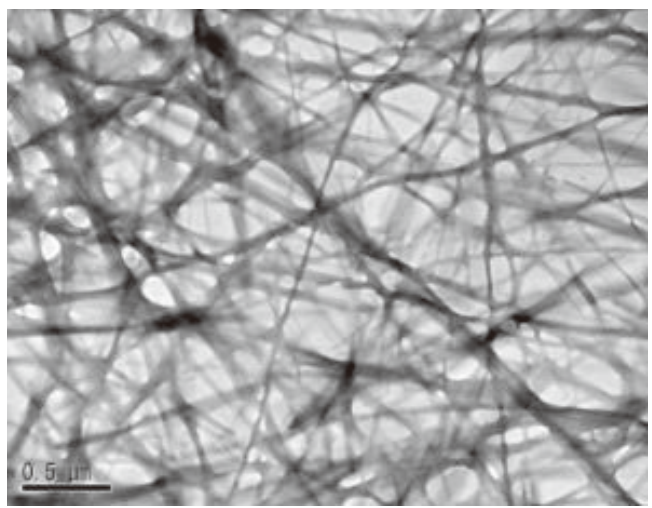

Fig.-5 Transmission electron microscope observation of $1.0 \mathrm{wt} \%$ GE-10-LL hydrogel.

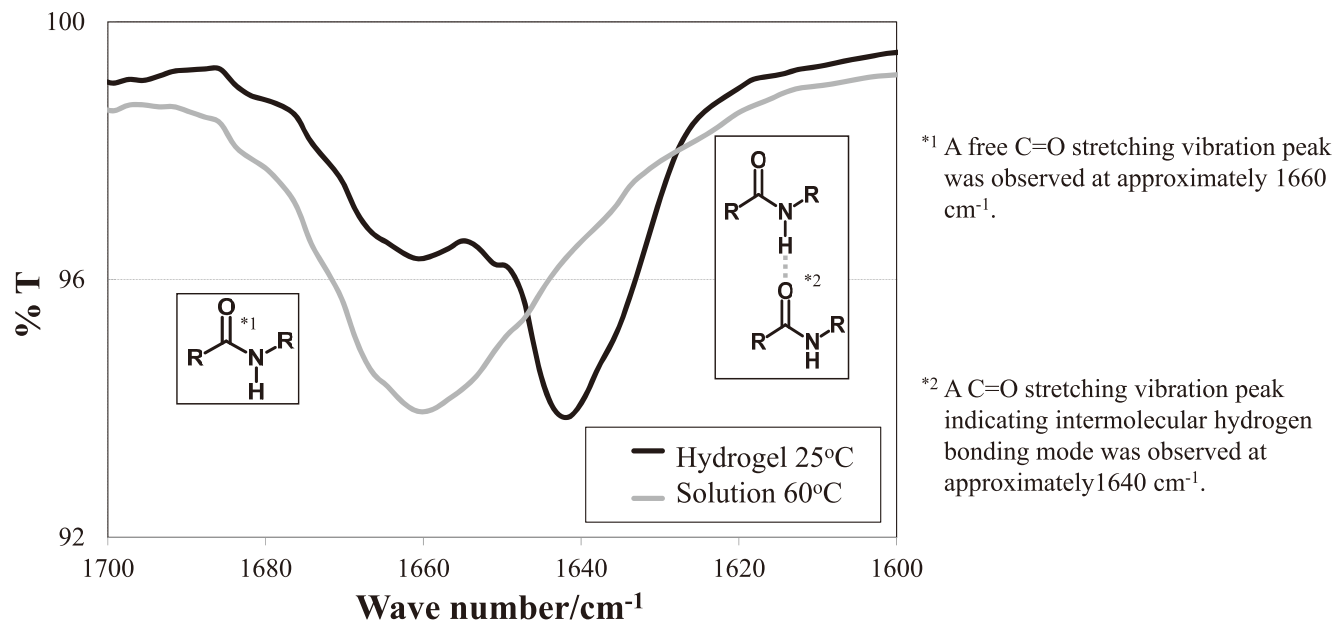

Fig.-6 FT-IR spectrum of GE-10-LL. 


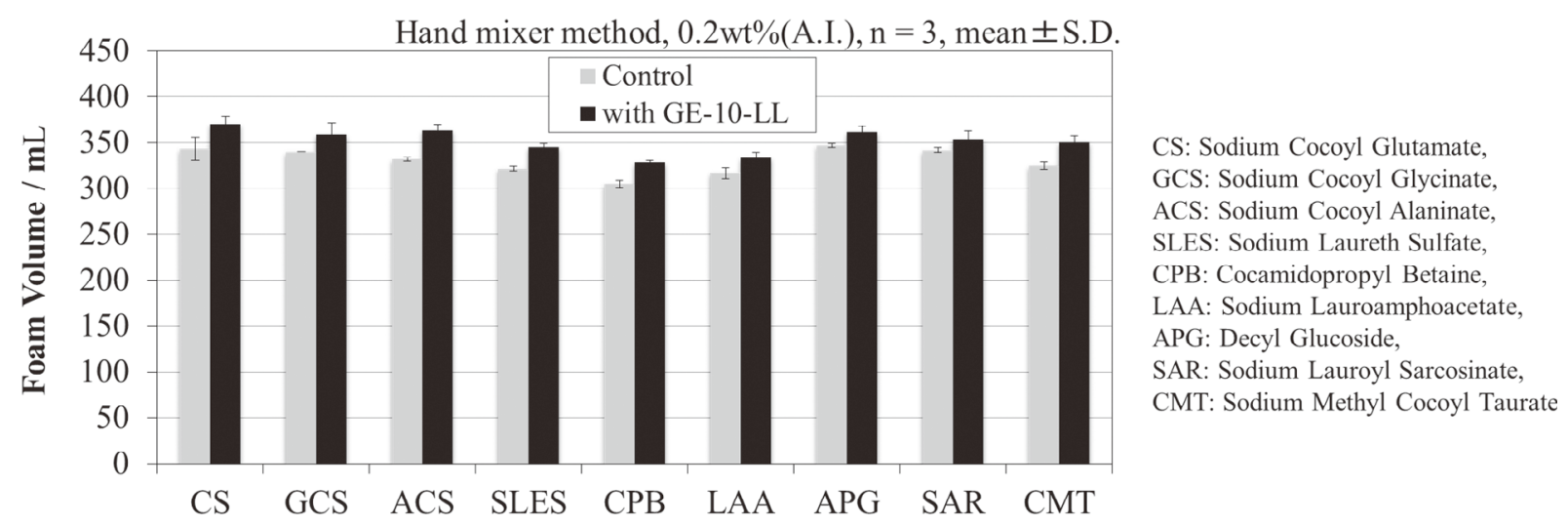

Fig. -7 Foam volume of various surfactants by the hand mixer method.

の各界面活性剂水溶液（Control）とそれらの水溶液にさ らに GE-10-LL 0.05 wt\%を添加した水溶液（with GE-10LL）を評価した。両者で界面活性片の有効成分濃度は異 なっているものの GE-10-LL 自身，単独では泡立ちがない 点, 添加量が少量である点, 泡立ち評価時には 50 倍に希 釈して測定している点から，これら水溶液の有効成分濃度 の差異は無視できるものと仮定し, 評価を開始した。泡量 の結果を Fig.-7に示す。GE-10-LLを添加することによ り，界面活性剂種を選ばず，総じて泡量が改善した。これ は，微量の GE-10-LL でさえも，そのジェミニ型界面活性 剤構造が有効に働き，増泡剂として働いている，もしくは 界面活性剤水溶液の粘度に影響は与えないものの界面活性 郕水溶液中に瀻維状会合体が存在しており, 泡沫の安定化 につながったものと推測する。

また，GE-10-LLを配合した界面活性剤で洗浄した毛束 は毛髪表面の摩擦係数が低下することや毛髪表面の疎水性 が向上する知見が得られた7)。この効果は， $N^{\varepsilon}$-ラウロイ ルリジンの滑沢性と高撥水性により発現していると推察 し，当初の目的であった $N^{\varepsilon}$-ラウロイルリジンの特長その ままに液体処方への配合を容易にする新規化合物の開発が 達成できた。

\section{4. ベシクル形成に関して}

1.で述べたと抢り，ジェミニ型界面活性剂は，単独で高 次分子集合体を形成しやすく, 濃度や pH を調整すること によって，ひも状ミセルやベシクルを形成することが知ら れている。また，アミノ酸を骨格としたジェミ二型界面活 性郕に関する報告も非常に多く，アルギニン8)やシスチン9), $\beta^{-ア ラ ニ ン ~}{ }^{10)}$ を使用した例があげられる。さらに, 多数 の論文でジェミニ型界面活性剂のスペーサー長と分子占有 面積や分子集合体形成能との関倸が報告されている ${ }^{11) ~ 13)}$ が, その相関関係は化学構造式に由来するところが非常に 大きい。

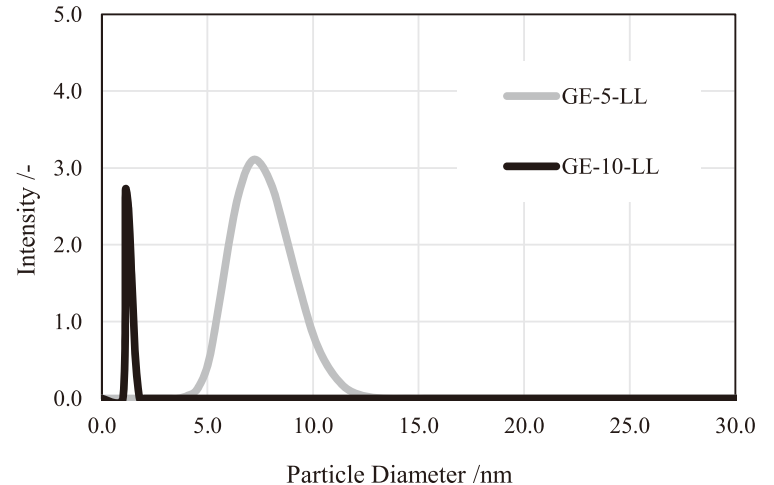

Fig.-8 Dynamic light scattering measurement of 1.0 wt\% GE-10-LL and GE-5 LL.

ここで, GE-10-LL と炭素鎖長 C5 であるグルタル酸で $N^{\varepsilon}$-ラウロイルリジンを架橋したジェミニ型誘導体 GE-5LL の分子集合体形成能を比較するために，動的光散乱法 を用いて各分子集合体の粒径分布を測定した（Fig.-8）。 結果, GE-10-LL の分子集合体の粒径は, GE-5-LL 比較し て小さいことがわかった。GE-10-LL はスペーサーが長い ため, 分子間凝集力が低下し, 結果として高次構造体を形 成しづらくなっていることが示唆された。

そこで，われわれは GE-10-LL でベシクルのような高次 分子集合体を形成させることを目的とし，ベシクル形成助 剤との併用系の検討を開始した。この検討を開始した理由 は，ベシクル形成助剂が GE-10-LL の分子内のアルキル鎖 長とスペーサー間の空間や GE-10-LL の分子間に配向する ことで, 高次集合体を形成しやすくなるのではないかと考 えたためである。

\section{5. ベシクル形成助剤の探索と基礎評価}

まず初めに、ベシクル形成助剤の探索を行った。有機性 值，無機性值，HLB などの因子を考虑して，油剤，ノニ 
オン界面活性剤を中心に約 20 種類の化粧品素材を選択 し, Table-2 に示す化粧品処方へ配合した際のベシクル形 成の有無を判定した。なお，ベシクル形成の判定基準は， 偏光顕微鏡によるマルテーゼクロス像の観察とした。

結果, 有機性值, 無機性值, HLB などの因子に相関関 係はなく，イソステアリン酸ステロールエステルをベシ クル形成助剤と選択したときにのみ GE-10-LL のベシクル が観察された。イソステアリン酸ステロールエステルのみ がベシクル形成能を示した理由については，イソステアリ ン酸コレステロールエステルの分子構造と GE-10-LLの分 子構造が立体的な相互作用が強かったためと考えられる。 すなわち，イソステアリン酸ステロールエステルと GE10-LL が疎水的相互作用や静電作用だけでなく, 立体化学 的に相互作用し，ベシクルを形成しやすい配列となったと 考察した。そのため, 分子サイズの異なるイソステアリル アルコールやコレステロールでは立体化学的に適さず, ベ シクル形成能を示さなかったと考察した。得られたべシク ルの偏光顕微鏡画像を Fig.-9に示す。無数のマルテーゼ クロス像が観察され, ベシクルの形成が示唆された。さら に，FF-TEM 画像を観察したところ，玉ねぎ様の多重膜構 造が観察された（Fig.-10）。

なお，当該マルチラメラベシクル（MLV）製剤のメデイ アン径は, $1.4 \mu \mathrm{m}$ であった。

Table-2 Formulation of vesicles.

\begin{tabular}{lc}
\hline & $(\mathrm{wt} \%)$ \\
\hline GE-10-LL & 1 \\
Auxiliary material & 2 \\
$\mathrm{pH}$ adjuster & to $\mathrm{pH} 6.0$ \\
Water & Balance \\
\hline Total & 100 \\
\hline
\end{tabular}

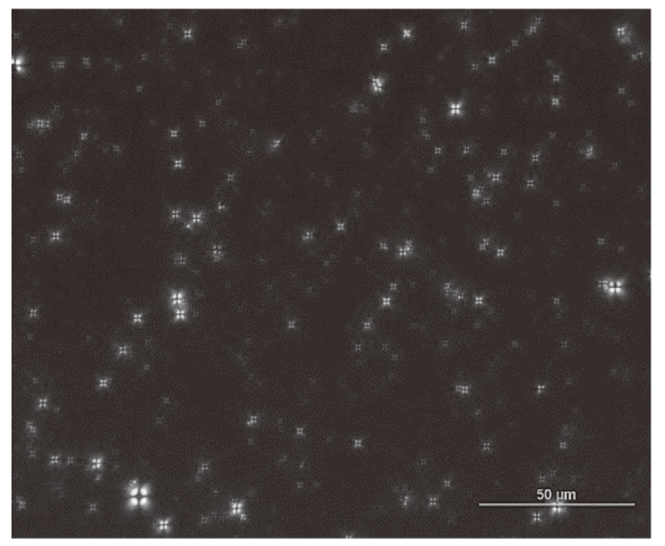

Fig.-9 Observation by polarization microscope.

\section{6. 角層浸透}

リポソームを代表とするベシクルは，有効成分を内包す る経皮吸収キャリアとして化粧品・医薬品の分野で応用さ れている ${ }^{14)}$ 。本節では，GE-10-LL が形成する MLVの経皮 吸収性に関して, in vivo 共焦点ラマン分光装置を用いて評 価した。in vivo 共焦点ラマン分光装置とは, 角層から得ら れるラマンスペクトルを検出することにより，非侵襲で成 分の浸透を評価することができる装置である。今回, MLV 製剂との比較試料として，通常のノニオン界面活性 剤（ポリソルベート80）でイソステアリン酸ステロール エステルを乳化した製剤（O/W emulsion）を選択した。 得られた比較試料の偏光顕微鏡画像を観察したが, ベシク ルの形成は確認できなかった。各製剤を被験者の前腕内側 部へ塗布し，1 時間後に測定した結果を Fig.-11に示す。 縦軸は，イソステアリン酸コレステロールエステルのラマ ンピーク強度，横軸は角層深さを示しており，ピーク強度 が大きくなるにつれて，浸透量が増加していることを意味 する。結果, MLV 製剤は比較試料である通常の乳化物と 比べて, 角層深さ $5 \mu \mathrm{m}$ 付近まで, 浸透量が優位に増加し

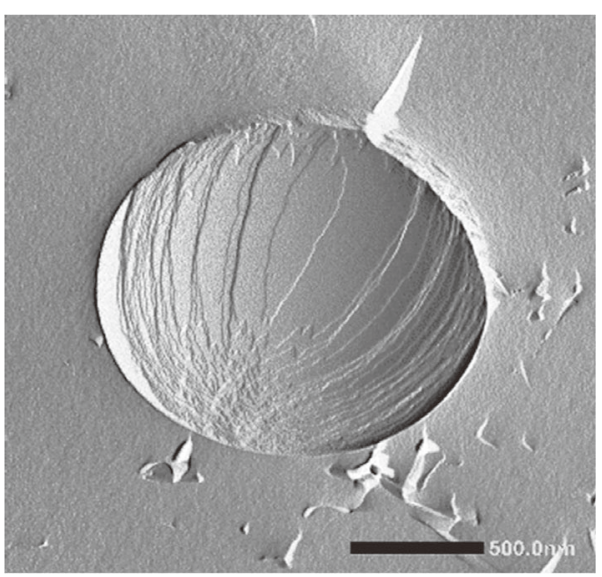

Fig.-10 Observation by FF-TEM.

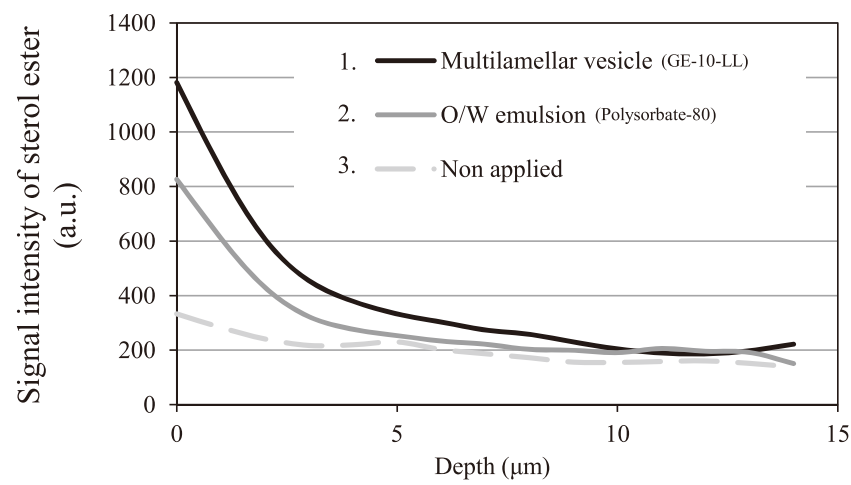

Fig.-11 Penetration of sterol ester into stratum corneum. 
ていることがわかった。なお，GE-10-LL は構造上アニオ ン性界面活性剤であるため, アニオン性界面活性剤により 角層を乱し, 浸透が促進された眯念もある。そこで, 被験 部位に GE-10-LL 水溶液を塗布した後，イソステアリン酸 コレステロールエステルを塗布するという２段階の工程で 処理した角層について浸透量を評価した。結果は, 各角層 深さで通常の乳化物と同等のラマンピーク強度となり, MLV ほどの浸透は確認できなかった。以上の結果より， GE-10-LL が形成する MLV 製剤は, 経皮吸収キャリアと して有効である可能性が示唆された。

\section{4. 結論}

$N^{\varepsilon}$-ラウロイルリジンとセバシン酸から形成されるジェ ミ二型界面活性剤である GE-10-LL は, pH 応答的にその 溶状を変化させ，とくに弱酸性〜中性領域でハイドロゲル を形成することがわかった。そのハイドロゲルは，分子内 に 4 つ存在するアミド結合が, 分子間において水素結合を 形成することで発現している。加えて, 分子の両端に伸び た疎水鎖，およびスペーサーによる高い疎水性相互作用か ら, GE-10-LL の自己集合体化，3 次元網目構造を形成す ることで水を抱え达み, 八イドロゲルを形成していること が示唆された。また, GE-10-LLは $N^{\varepsilon}$-ラウロイルリジン 由来の高い滑沢性と撥水性を有し, 洗浄料へ配合すると増 泡効果を付与することがわかった。

さらに, GE-10-LL はイソステアリン酸コレステロール エステルと組み合わせることにより，マルチラメラベシク ルを形成した。これは, イソステアリン酸コレステロール エステルが GE-10-LL の曲率を最適化し, 高次集合体を形 成しやすくなったためと推測する。in vivo 共焦点ラマン分
光装置により, 得られたマルチラメラベシクルの角層への 浸透性を評価したところ, 通常の乳化物と比較して, 優位 に浸透することが示唆された。

\section{引用文献}

1）上土井智数, フレグランスジャーナル，38(2), 50-54 (2010)

2) F. M. Menger, C. A. Littau, J. Am. Chem. Soc., 115, 1008310090 (1993)

3) M. Johnsson, A. Wagenaar, J.B.F.N. Engberts, J. Am. Chem. Soc., 125, 757-760 (2003)

4) L. Pérez, A. Pinazo, R. Pons, M. R. Infante, Adv. Colloid Interface Sci., 205, 134-155 (2014)

5）英 謙二, 白江芳房, ゲルハンドブック，エヌ . ティー・エス, 1997, p. 312-319

6） R. M. Silverstein, F. X. Webster, D. J. Kiemle, 有機化合物 のスペクトルによる同定法一MS, IR, NMR の併用一, 東京化学同人, 1999, p. 110

7）小林 瞬, フレグランスジャーナル，44(8), 62-68 (2016)

8) M. C. Moran, M. R. Infante, Green Chem., 6, 233-240 (2004)

9) D. M. Lewis, J. Soc. Dye. Colour., 106, 270-274 (1990)

10) H. Kunieda, K. Tsubone, Langmuir, 16, 6438-6444 (2000)

11) L. Pérez, M. A. Pinazo, M. J. Rosen, R. Infante, Langmuir, 14, 2307-2315 (1998)

12) A. Pinazo, X. Wen, L. Pérez, M. R. Infante, E. I. Franses, Langmuir, 15, 3134-3142 (1999)

13) E. Alami, G. Beinert, R. Zana, Langmuir, 9, 1465-1467 (1993)

14） V. B. Patravale, S. D. Mandawgade, Int. J. Cosmet. Sci., 30, 19-33 (2008) 